https://doi.org/10.31470/2706-7904-2020-15-72-76

\title{
ПСИХОЛІНГВІСТИЧНІ МАРКЕРИ ДИСКУРСУ \\ ГІБРИДНОЇ ВІЙНИ
}

Psycholinguistic Markers of Hybrid Warfare

\section{Viktoriia Dumanska}

Graduate Student

National Academy of Security Service of Ukraine

vdumanskaya@gmail.com

https://orcid.org/0000-0002-4157-9560

\begin{abstract}
In thesises the analysis of psycholinguistic markers of hybrid war is carried out, its verbal dimension is considered. The meaning of the term «language of aggression» is also revealed, examples of its use in Ukraine and Russia are given. The means of presenting information on Russia's hybrid war with Ukraine have been formalized. It was determined that Russia very often uses propaganda methods of empathy and works with programmed reactions. So in order to resist the aggression of the Russian Federation, Ukraine must improve its own information field, primarily by improving the verbal component of hybrid warfare.
\end{abstract}

Key words: hybrid war, information-psychological influence, discourse of war, language, information product.

\section{Вступ \\ Introduction}

Гібридна війна - це особливий вид збройного конфлікту, що поєднує в собі військові, дипломатичні, інформаційні та інші засоби для досягнення політичних $\mathrm{i}$ стратегічних цілей держави. Фізичні військові дії постійно супроводжуються процесами їхнього словесного опису та аналізу. Збройне зіткнення будь-якого рівня починає існувати як війна - тільки в межах її вербального осмислення.

Можна констатувати, що проти України широко використовуються сучасні різноманітні технології негативних інформаційно-психологічних впливів, які загрожують національному інформаційному простору та сувернітету держави. Гарантування інформаційної безпеки України в умовах дестабілізуючих негативних інформаційнопсихологічних впливів та експансіоністської агресивної інформаційної політики 
Російської федерації, потребує консолідації зусиль на усіх рівнях державної влади та громадянського суспільства. Саме ця теза підтверджує актуальність даного дослідження.

Метою дослідження $є$ аналіз стану українського інформаційного поля в умовах гібридної війни в контексті психолінгвістики.

\section{Методи та методики дослідження}

\section{Methods and Techniques of the Research}

Більшість сучасних досліджень, які безпосередньо або опосередковано розглядають тему гібридної війни в контексті мовознавства, присвячені розгляду інтерпретаційної складової гібридної війни, що реалізується за допомогою дискурсивних вербально-семіотичних засобів.

Для дослідження комунікативно-прагматичних характеристик дискурсу гібридної війни, які зумовлюють процес комунікації у даному середовищі було використано дискурс-аналіз; а 3 метою визначення особливостей мовленнєвої взасмодії учасників комунікації - прагматичний аналіз, елементи конверсаційного аналізу дозволили охарактеризувати особливості мовленнєвої взаємодії учасників гібридних конфліктів.

Аналіз останніх публікацій свідчить, що теоретичні проблеми регулювання мовної діяльності суспільства, механізми маніпулювання мовою, проблеми влади та ідеології досліджували такі вчені як: Г. Яворська, О. Гойман, Г. Почепцов; проблематика сугестивних технологій маніпулятивного впливу, питання сугестивної лінгвістики висвітлювалися в наукових працях таких авторів: В. Петрик, Л. Компанцева, М. Присяжнюк, С. Скулиш, В. Остроухов.

\section{Результати \\ Results}

У гібридній війні широко використовується мова агресії, що стала найпомітнішим та яскравим показником конфлікту. Поява великої кількості нових, експресивно забарвлених негативних лексем, що використовувалися як семіотичні маркери належності до однієї із сторін конфлікту, стали діагностичним показником гостроти протистояння.

Специфіка інформаційної складової в російсько-українській війні, порівняно із попередніми гібридними конфліктами полягає в:

(1) інтенсивності та широті охоплення аудиторії інформаційних впливів, яка набула глобального масштабу; 
(2) систематичному й комплексному застосуванні медійних та новомедійних засобів, з особливою роллю соціальних мереж;

(3) створенні нового дискурсу війни, спрямованого на руйнування існуючих i формування нових, переважно фальшивих та викривлених інтерпретаційних і смислових механізмів сприйнття дійсності (Горбулін, 2017).

Аналіз мови гібридної війни передбачає увагу насамперед до іï вербальної складової та створюваних за іï допомогою соціально-семіотичних конструктів (Парахонський \& Яворська, 2019).

Одним із наслідків «гібридної війни» стало становлення якщо не імперського, то майже імперського мовлення в Росії, оскільки саме воно є базою експертного середовища, яке забезпечувало підтримку війни. В Україні, навпаки, суспільством було активовано антиімперське мовлення. Радянський Союз лише умовно можна визначати як імперію, а от відмова від режиму та установок Радянського Союзу, а саме заборона в Україні російського інформаційного і віртуального продукту - $\epsilon$ безпосереднім прощанням з імперією.

До початку війни в Україні більшість громадян активно використовували російський інформаційний продукт: і у фізичному, і у віртуальному просторі. Він і формував відповідну модель світосприйняття. Розрив із цією російькою моделлю за відсутності адекватної власної буде мати негативні наслідки, але через цей процес Україна повинна пройти в будь-якому випадку.

Аналізуючи роботи вчених, що досліджують проблеми в сфері інформаційної безпеки (Дзьобань, 2015; Ткачук, 2017; Ліпкан, 2011; Богуш, 2005; Максименко, 2011; Желіховський, 2011; Довгань, 2018; Жарков, 2009; Почепцов, 2015; Сопілко, 2015 та ін.), вітчизняні та зарубіжні 3МI, можна дійти висновку, що вплив російських каналів на свою цільову аудиторію $є$ неймовірно успішним. Але це виявилося максимальним програшем для Росії стосовно українських глядачів, так як вони бачили в подачі російських телеканалів вкрай істотне спотворення дійсності та інформації, що подається урядом для людей.

Так, Росія формалізувала засоби подачі інформаџії стосовно гібридної війни з Украӥною таким чином:

(1) засоби подачі інформації часів Другої світової війни («бандерівці», «карателі», «фашисти») або ії відголоску у сьогоденні («неонацисти»);

(2) засоби подачі інформації часів Радянського союзу («возз’єднання Криму», «Крим наш»); 
(3) засоби подачі інформації, що відображали легітимність донецьких та луганських протестувальників проти київської влади («народний мер», «народний референдум»);

(4) засоби подачі інформації, що відображали незаконність влади («самопроголошені керівники», «нелегітимна влада», «хунта»). Наприклад, мер, якого обирали просто неба, без жодного законодавчого підгрунтя, ставав «народним», цим начебто й забезпечувалася його легітимність. На жаль, ніхто не допускав думки про те, що в нього, наприклад, може бути російський паспорт.

Україна, діючи за подібним сценарієм, також створювала подібні повідомлення, на киталт:

(1) задіяність Росії («проросійські сили»);

(2) «терористи», що дало змогу використати світову практику боротьби 3 тероризмом, як це свого часу зробила Росія в боротьбі з чеченським сепаратизмом;

(3) «бойовики» для характеристики свого противника. Але це визначення мало суттєвий недолік, адже обмежувало розуміння того, що серед них українці, що мобілізовані новою, начебто народною владою, які виступають проти російської агресії.

Як можна побачити, пропагандисти надають перевагу використанню виключно негативної термінології, в контексті опису дій та самого супротивника. Обидві сторони розповідають про свої виграші та програші противника. Вони роблять це на постійній основі вже не перший рік, збиваючи з пантелику народ, адже війна триває вже не перший рік. Не виключається варіант, що за таких умов серед політиків та звичайних людей, можуть активізуватись прихильники війни, а не миру (Клімкін, 2015: 9).

Варто зазначити, що Росія дуже часто використовує пропагандистські прийоми емпатії, розраховуючи на те, що в певних випадках зайва емоційність часто блокує раціональність. Крім того, російська пропаганда працює із запрограмованими реакціями. Вона формує їх так, щоб у споживача інформації не залишалось вільного вибору. При цьому Росія робить значні капіталовкладення, щоб переконати у свойй правоті зарубіжного споживача новин, чого немає в Україні.

Існує певна частка людей у Свропі та США, що активно підтримують точку зору Росії стосовно України. Це відомі журналісти, політологи, історики, колишні дипломати, навіть актори та співаки. Вони можуть «перетягнути» на свій бік будь-яку аудиторію, через вагомий вплив на свідомість людей (Снитко, 2017: 207-215). На даний час Україна також розпочала роботу із зарубіжною аудиторією, включаючи і російську.

Саме тому «Україна має вкладати фінанси у створення власного якісного інформаційного продукту, що буде відповідати сучасним вимогам. Він повинен бути:
(а) високоінтелектуальним;
(б) мати
багато
різновидів;
(в) формувати власну, 
унікальну модель світу; (г) давати відповіді на власні, внутрішні, а не чужі проблеми» (Почепцов, 2015).

\section{Висновки \\ Conclusions}

Феномен гібридної війни має два головні виміри - матеріальний (фізичний) і інформаційний. Ці два виміри є протилежними. У віиськовому (фізичному) вимірі конфлікт України та Росії є локальним і охоплює частину території України, натомість масштаби гібридної війни виходять далеко за межі частини певної території.

В гібридній війні широко використовується мова агресії, що стала найпомітнішим та яскравим показником конфлікту. Поява великої кількості нових, експресивно забарвлених негативних лексем, що використовувалися як семіотичні маркери належності до однієї із сторін конфлікту, стали діагностичним показником гостроти протистояння.

Рекомендації. Цілеспрямована концентрація зусиль стосовно покращення українського інформаційного поля, насамперед шляхом вдосконалення вербальної складової гібридної війни, допоможе впоратись $з$ наявними викликами.

\section{Лiтература References}

Горбулін, В. (2017). Світова гібридна війна: український фронт. Національний інститут стратегічних досліджень. Київ: НІСД.

Дзьобань, О.П., Соснін О.В. (2015). Інформаційна безпека: нові виміри загроз, пов'язаних із інформаційно-комунікаційною діяльністю. Гуманітарний вісник Запорізької державної інженерної академії, 61, 24-34.

Клімкін, П. (2015). План агресора: щоб «партія війни» перегризла горло «партії миру». Високий замок, 113, 9.

Парахонський, Б.О., \& Яворська, Г.М. (2019). Онтологія війи і миру: безпека, стратегія, смисл. (Монографія). Киї: НІСД.

Почепцов, І. (2015). Сучасні інформачійи війи. Київ: Вид. дім «Києво-Могилянська академія».

Снитко, О.С. (2017). Проекти тотального зомбування в інформаційному просторі України.

Інформаційа безпека людини, суспільства, держави. Вісник Національної академї Служби безпеки України, 1(21), 207-215.

Ткачук, Т.Ю. (2018). Забезпечення інформаційої безпеки в умовах євроінтеграції України: правовии вимір. (Монографія). Київ: ВД «АртЕк». 